\title{
Prugberger Tamás
}

\section{A Fidesz-KDNP-pártszövetség választási gyốzelmének tényezói és a kormányzati munka új kihívásai}

\author{
On the Factors of the Winning \\ of the Fidesz-KDNP Party and the \\ New Challenges of the Governance
}

\section{Összefoglalás}

A tanulmány elsô fejezete a Fidesz-KDNP 2018. évi parlamenti választásokon elért fölényes gyôzzelmének oktényezôit elemzi. Kimutatja, hogy ehhez a migránsválságnak az ország érdekeinek megfelelố kezelése, a gazdaság és a hazai vállalkozási szféra lehetôségeinek a növelése, a munkanélküliség radikális lecsökkentése, a devizahitelesek megsegítése, valamint az ellenzéki pártok egymás közötti rivalizálása és koncepciótlansága vezetett. A második fejezet Brüsszel és a Soros-hálózat ellenintézkedéseivel, a választásokat követố ellenzéki tüntetéssorozat kifulladásával, az Orbán-kormányt támadó Sargentini-jelentéssel és kritikájával, valamint a migránsbevándorlással szembeni védekezést jelentố törvénycsomaggal foglalkozik. Végül a harmadik részben a szerzô saját észrevételeivel együtt bemutatja a választást követôen kiépített új kormányzati struktúrát.

Kulcsszavak: alapítványok, Európai Bizottság, Európai Parlament, jogállamiság, migráció, NGO, parlamenti választás, Sargentini-jelentés, transzatlantiság

Prof. dr. Prugberger Tamás DSc, egyetemi tanár, Miskolci Egyetem, Debreceni Egyetem (prugberger.tamas@tonline.hu). 
Prugberger Tamás: A Fidesz-KDNP-pártszövetség választási gyốzelmének tényezôi...

\section{Summary}

The first chapter of the essay focuses on the factors of absolute winning of the FideszKDNP party on the parliamentary election of 2018. It points out that the success derives from the proper migration treatment, the enhancement of the opportunities of economy and Hungarian entrepreneurs, radical decrease of unemployment, support of foreign currency loans, rivalry and lack of concept on behalf of the opposition. The second chapter focuses on the countermeasures of Brussel and Soros-network, failure of the opposition demonstrations, the Sargentini report attacking and criticizing the Orban-government, and the legislative package on the migration treatment. The third chapter summarises the author's remarks on the new governmental structure.

Keywords: foundations, European Commission, European Parliament, rule of law, migration, NGO, parliamentary election, Sargentini report, Transatlantic

\section{A VÁlASZTÁSI GYÓZZELEMHEZ VEZETÓ TÉNYEZÓK}

A Fidesz-KDNP-pártszövetségnek a 2018. április 8-ra kitûzött parlamenti választáson elért, egymást követố kétharmados választási gyôzelmi sorozata a 2010. évi áprilisi országgyúlési választással kezdődött, amely megismétlődött a 2014. évi parlamenti választáson, és folytatódott ez év tavaszán is. Ezt megelôzóen az 1998. évi parlamenti választásokat relatív többséggel nyerte meg, és ezért koalíciós kormányzásra kényszerült. Koalíciós partnere a Torgyán József vezette Kisgazdapárt lett, amely sok tekintetben nehezítette a kormányzati munkát. ${ }^{1}$ Ennek ellenére az Orbán Viktor által irányított koalíciós kormányzás alapvetôen sikeres volt, teljesíteni tudta választási ígéreteit. Legnagyobb eredménye a balliberális Horn-kormány mandátumának elsô idôszakában bekövetkezett, pazarlással megnövekedett adósságállomány közel 60\%-ra történô leszorítása lett, amelyet ezt megelôzően a Horn-kormány második pénzügyminisztere, Bokros Lajos az 1995. évi márciusi antiszociális, egyben szakmailag megkérdôjelezhetố megszorító pénzügyi csomagjával nem tudott lecsökkenteni (Gazdag, 2017a:33-34). Ezért a Horn-kormány a privatizáció továbbfolytatásával igyekezett az államháztartás helyzetén javítani, amelynek során katasztrofálisnak bizonyult az ország energiaellátásának multinacionális vállalatok részére történô, teljes privatizálása, amellyel az ország nyugati tốketársaságoktól való gazdasági függését teljessé tette (Prugberger, 2009:7, 17; 2005:35-36). Ugyanis a korábbi, Antall József és Boross Péter miniszterelnökök vezette MDF-Kisgazda koalíciós kormányzás idôszakának privatizációs folyamatában az élelmiszeripar és mezôgazdaság privatizációval és termőföldeladásokkal történó tönkretételét (Lentner, 1996:45; Prugberger, 1997:347-348) a Horn-kormány tovább folytatta a kereskedelem és a vendéglátás, valamint az ipari termelés multinacionális cégek részére történố eladásával (Lentner, 1996:3-4; Prugberger, 1993:42-47; Prugberger, 2009). Mindez a hivatali apparátusnak és az akkori kormány holdudvarának jelentôs hasznot hozott, az államháztartásnak azonban szinte semmit. Az elsô Orbán- 
kormány a mandátumciklusának utolsó évében igyekezett csökkenteni e károkat viszszavásárlások tervbevételével, amire azonban a 2002. évi választási veresége következtében nem kerülhetett sor. ${ }^{2}$

A 2002. évi tavaszi választások eredményeként Medgyessy Péter miniszterelnökségével hatalomra került MSZP-SZDSZ koalíciós kormány elsố közel kétéves idôszaka után az SZDSZ által megpuccsolt miniszterelnök helyére a kormánykoalíció Gyurcsány Ferencet ültette a miniszterelnöki székbe, aki az államadósságot jóval $80 \%$ fölé duzzasztotta, dilettáns kormányzati tevékenysége pedig a megnövelt államadóssággal és a $8 \%$ körüli költségvetési hiánnyal államcsôd közeli helyzetbe sodorta az országot. Végül lemondani kényszerült, helyére Bajnai Gordon került, aki csak egy hatalmas, rövid lejáratú IMF-hitellel tudta megmenteni Magyarországot az államcsôdtôl. A korrupciós visszaélések és az életszínvonal nagymérvú csökkenése hozta meg a Fidesz elsố kétharmados választási gyôzelmét 2010-ben, és söpörte el a balliberális kormányzást, amelynek belátható idôn belüli visszatérésére sem a választók többségének a kijózanodása, sem az ellenzéki pártok egymás közötti hatalmi harcai, sem pedig általános és szakmai politikai felkészültségének a hiánya miatt vélhetooleg kevés az esély.

A 2010-ben abszolút többséggel hatalomra került második Orbán-kormány 2014-ig tartó kormányzati munkájának elsô másfél évében a Horn-kormány által kötelezôvé tett, magánnyugdíjpénztárakba (az új biztosítottak esetében kötelezô, a régiek számára fakultatív) történő befizetések egy részét a Bajnai által felvett kölcsön visszafizetésére használta fel (Prugberger, 2011; Barta, 2011). Ezáltal megszúnt az IMF-től való függôség, és az ország pénzügyi és gazdaságpolitikai szempontból függetlenné vált. Másfél évvel a kormányváltás után az Orbán-kormány megkezdhette unortodox gazdaságpolitikájának megvalósítását (Prugberger, 2018a:16), amely mindmáig sikeresnek bizonyult. Az államadósság folyamatosan csökken, mára $70 \%$ körül jár, ennek eredményeként a hitelminôsítô cégek egyre kedvezôbb minôsítéssel tartják befektetésre alkalmasnak Magyarországot. Több külföldi cég telepedett le tartósan Magyarországon, elsósorban az autóiparban úgy, hogy a balliberális kormányok gazdaságpolitikájától eltérôen, hasznuk egy részét itt fektetik be, és nem viszik ki a teljes hasznot az országból, ezenkívül adófizetési kötelezettségüknek korrekt módon tesznek eleget. Mindezek következményeként, elôször a közmunkaprogrammal, majd ennek fokozatosan, rendes foglalkoztatási formák felváltásával tartósan $5 \%$ alá csökkent a munkanélküliség, a bérek pedig a 2018. évi harmadik kétharmados eredményt hozó parlamenti választásokig átlagosan közel 10\%-kal nôttek, míg az uniós átlag csak 3\%-ot mutat fel e téren. ${ }^{3}$

Ezek a 2010 óta folyamatosan jelentkezô eredmények, amelyhez a 2014. évi parlamenti választásokon ugyanúgy, mint a 2018. évin, hozzájárult az ellenzéki pártoknak és az ellenzékivé vált külön utas Jobbiknak egymással szembeni hatalmi rivalizálása, valamint kormányprogramjuk koncepciótlansága. Ugyanakkor a jelenlegi, mindennél stabilabb választási győzelemhez egyértelmúen hozzájárult a 2015-ben elindult tömeges migrációs krízis. A harmadik Orbán-kormány már 2016-ban a schengeni és az uniós tagországi határok lezárásával kívánta az afrikai és kis-ázsiai illegális, valamint köz- és szociális biztonságot veszélyeztető tömeges muszlim bevándorlást leállítani, és elérni azt, hogy az Európai Bizottság ilyen irányú intézkedéseket hozzon. Ennek ér- 
dekében zárta le már 2015 ôszén az ország Szerbiával közös déli határát, valamint katonailag és rendôrileg ügyel arra, hogy migránsok illegális módon, Magyarországon keresztül ne juthassanak az európai kontinensre. A helyzet ugyanis az, hogy az Obama-kormány 2010-ben az arab tavasz meghirdetésével, a demokrácia jelszavával szándékosan heccelte fel az arab államok népességét a kétségtelenül autokrata arab állami vezetókkel szemben, akik diktatórikus politikájukkal stabilitást, rendet, szociális és egzisztenciális biztonságot nyújtottak országuk népességének. Az USA demokrata párti adminisztrációja egy forradalmi hullámot indított el csak azért, hogy eme államokban anarchikus állapotok alakuljanak ki, amelyeknek a polgárait a létbizonytalanság következtében tömeges Európába menekülésre késztetik. Ily módon az USA demokrata párti politikájának célja, hogy Európa gazdaságát teljesen az USA gazdasági céljainak rendelje alá, amit mintegy 15 évvel ezelôtt már meg akart valósítani a MAE-nak nevezett transzeurópai atlanti szabadpiaci együttmúködés létesítésével. Ezt azonban akkor az európai nemzeti államok ellenállása meghiúsította. Ezért az USA az általa kidolgozott Transzatlanti Kereskedelmi és Befektetési Partnerséget (TTIP) igyekszik véghez vinni, melyben a fogyasztó-megrendelô az USA kívánsága szerint létrehozandó Európai Egyesült Államok és cégei, míg a szolgáltatók az USA és a vállalatai lennének, ahol az USA gazdasági fölényét és Európa kiszolgáltatottá válását az valósítaná meg, hogy jogvita esetén a szolgáltató és a befektetô cégek jelölnék ki a vitát eldöntô bíróságot. Minthogy az elnöki székben a demokrata párti Obamát felváltó Donald Trump e politikával szemben az egyenjogú kölcsönös partnerségen alapuló szerzôdésekkel kívánja a középosztály, nem pedig a felsô elit érdekeinek megfelelően az USA gazdaságpolitikáját alakítani, ezért a jelenleg ellenzékbe szorult demokrata irányvonal felgyorsított aktivitással igyekszik visszafordíthatatlan helyzetet kialakítani a saját elképzelésének megfelelően. Vagyis el szeretné elérni, hogy Európát minél előbb elárassza a muszlim bevándorlók tömege, amely az államok nemzeti jellegét felszámolná, és az USAhoz hasonló, prezidenciális berendezkedésú Európai Egyesült Államok létrejöttével a TTIP-et realizálná.

A magyar választópolgárok a 2018. áprilisi parlamenti választások során nagyra értékelték azt a tényt, hogy az Orbán-kormány következetesen lezárta a határokat, és nem tette lehetôvé az illegális migráns bevándorlást az országba, ami által nem következtek be a külföldön megszaporodott, esetleges terrorakciók és fôleg nôkkel, valamint fiatalkorúakkal szembeni csoportos migránsletámadások. Az állampolgárok többsége morálisan is elítélte az Európai Unió által képviselt transzatlanti, a szúk fináncoligarchia érdekeit kiszolgáló, egypólusú globális gazdaságpolitikát, amelynek uszályába szegődött a magyar balliberális ellenzék és lényegében a Jobbik is. A Sorosalapítványok különböző tanfolyamokkal megpróbálták a migránsok irányában „érzékenyíteni” az igazságszolgáltatás szereplőit, bírákat, ügyészeket, ügyvédeket egyaránt. Mindez csak részben járt sikerrel.

A kontinentális európai ítélkezési gyakorlattól idegen az angolszász, fóleg amerikai jogszolgáltatási gyakorlat, amely szerint politikai nézôpontok alapján lehet elbírálni az egyes ügyeket, sôt a tételes jogi előírásokat is behatárolás nélküli szabad értelmezéssel lehet interpretálni a különbözô oldalakról jelentkezô érdekmegnyilvánulások alakulása 
szerint. Ennek megfelelően magyarázza az USA Legfelsôbb Bírósága, az alkotmánybírósági szerepet is betöltve, az USA alkotmányát, a szövetségi törvényeket, és ez a jogszolgáltatási módszer gyúrúzik le az alsóbb szintekre. Úgy tûnik, hogy ennek Németországra irányuló hatására a frankfurti szociáldemokrata filozófiai irányzat habermasi torzítása kétféle morálról, egy alacsonyabb szintû és „kevésbé értékes”, közmorálról és az elit által kialakított, magasabb rendú „diszkurzus morálról” értekezik, amelyre a jog is épül (Pokol, 2015). Ezt az eltorzított harmadik utas szociáldemokratának nevezett ideológiai szemléletet ma már Németországban is egyre többen kritizálják, nemcsak az Egyesült Királyságban, ahol ennek a következtében kellett az e nézetet képviselő Tony Blairnek lemondani (Friedrich Ebert Alapítvány, 2003). ${ }^{4}$ Úgy tûnik, mindeme eltorzult gazdasággal összefüggó migrációval kapcsolatosan Orbán Viktor politikai állásfoglalása kezd uralkodóvá válni nemcsak a V4-ek Kelet-Közép-Európájában, hanem Európa nyugati felében is (Magyar Idők, 2018:12-13; Szôcs László, 2018b:7; 2018a:9). Szemben az egyre destruktívabb szerepet felvállaló ENSZ-szel, amelynek jelenlegi fótitkára, Antonio Guterres immár másodszor nyilatkozik meg akként, hogy a korlátok nélküli migráció nemcsak elkerülhetetlen, hanem szükséges is, mert hasznos Európa számára, ugyanis a népességcsökkenés miatt veszélyessé váló európai munkaerôhiányt a bevándorlás enyhíteni tudja (MH, 2018:5). Ennek azonban ellentmond, hogy a migránsok többsége az alulképzettségük miatt hasznos munkát végezni nem tud, de nem is akar, hanem a szociális segélyból kívánja fenntartani magát. Ma már nemcsak a magyar választók többsége, hanem a nyugat-európai kormányok is egyre szélesebb körben helyt adnak az Orbán Viktor által már 2015 óta képviselt nézetnek, mely szerint kettôs határvédelem szükséges, azaz az egyes államoknak meg kell védeniük a saját határaikat, az Európai Uniónak pedig a schengeni határokat a migráns beözönlések elól, illetve az Európai Unió határain kívül kell megvizsgálni az Európába betelepülni szándékozók munkaerô-alkalmasságát, valamint azt, hogy ki politikai menekült. Az illegális bevándorlókat pedig, kiutasítás mellett, vissza kell szállítani saját hazájukba (Magyar Idôk, 2018:12-13; Szốcs László, 2018b:7; 2018a:9).

A másik tényezô, amely a Fidesz-KDNP-kormánykoalíció harmadik kétharmados gyôzelmét elôsegítette, abban rejlik, hogy a választók nagy többsége rájött arra, hogy a kormánykoalíció szakszerúen irányítja a gazdaságot, és közben a lehetôségekhez mérten a lakosság szociális felemelkedésére is gondot fordít. Ez mutatkozott meg a Hornkormány már kritizált energiaprivatizációjával összefüggő, ugrásszerúen megemelkedett rezsiköltségek lecsökkentésében, ami az energiaárak határok közé szorításában is megmutatkozott. A kormány tőle telhetôen gondoskodott arról, hogy a Gyurcsánykormány idején a kormány által propagált devizahitelek felvételébe „beugrasztott” és emiatt eladósodott, sokszor az árverezések miatt hajléktalanná vált tömegek a teljes kifosztás elől megmeneküljenek. Ma már köztudomású, hogy a Gyurcsány-kormány a svájci és a japán hitelintézetekkel összejátszva, pénzügyi trükkel múvileg felértékelte eme országok valutáját, míg a magyar forintot a Nemzeti Bankkal leértékeltette, ami által a devizahitelek kamatja egészen alacsonyra, míg a magyar forinté magasra változott. Ezzel az akkori balliberális kormány a devizahitelek felvétele irányába terelte a kedvezố hitelfelvételi lehetôségeket keresô lakosságot, és amikor ez a hitelfelvételi piac telítetté vált, egy másik hasonló pénzügyi trükkel az MNB leértékelte az említett két 
külföldi valutát, míg a forintot felértékelte. Ezáltal a devizakamat folyamatosan emelkedett, amit a hitelesek jelentôs része nem tudott törleszteni. A Gyurcsány-kormány e gazdasági lépésüket azzal igyekeztek legitimálni, hogy mindez azért vált szükségessé, mert Magyarországon nagyon magas a munkanélküliségi ráta. Ennek pedig az az oka, hogy ellentétben a nyugat-európai államok bérlakásban éló, mobil munkavállalóival, a magyar lakosság túlnyomó része lakástulajdonhoz kötöttsége folytán nem mobilis. Ezért ez a legalkalmasabb eszköz ahhoz, hogy a lakosságot meg lehessen szabadítani ingatlantulajdonuktól, és bérlakásba költözésre ösztönözzék óket. Ezzel párhuzamosan ez a balliberális kormányzó és kormányközeli holdudvar, amit a privatizáció alatt illegitim módon összegrundolt magának, csak részben fektette be a gazdaságba, inkább megfelelő ellentételezés mellett nyugat-európai és transzatlanti multinacionális cégeknek játszotta át, amely cégeket pedig magának megtartott, képtelen volt hosszú távon nyereségesen üzemeltetni. Ezért sorra mentek tönkre ezek a vállalatok, amelynek következtében beszállító gazdaságok és alvállalkozó cégek tömege maradt jövedelem nélkül, munkavállalók tömege vált munkanélkülivé (Prugberger, 2009).

Ezzel szemben a jelenlegi Fidesz-KDNP-kormány olyan cégbirodalmakat segített felépíteni, amelyek fôvállalkozóként tevékenykedve kis- és közepes méretú cégeket, egyéni és társas vállalkozásokat, valamint munkavállalókat foglalkoztatnak. Ennek tulajdonítható, hogy az Orbán-kormány által elindított közmunkaprogram meglehetôs gyorsasággal alakul át rendes foglalkoztatássá, aminek eredményeként ma már tartósan $5 \%$ alatt van a munkanélküliségi ráta, illetve mostanra átlag 10-13\%-kal nôttek a bérek, és a gazdasági, valamint a szociális partnerek részvételével ma már nemcsak a minimálbéreket határozza meg a kormány, hanem az egyes szakmák, foglalkozások garantált bérminimumát is (Prugberger, 2018a:16-17). Mindezt a lakosság többsége megérezte, és hidegen hagyta az ellenzéki pártoknak a kormányt befeketíteni igyekvô propagandája. Ebbe belejátszott az is, hogy a felnôtt lakosság még jól emlékezett a korábbi balliberális kormányzatok korrupciótól sem mentes politikájára (Prugberger, 2009).

Végezetül a választás kimenetelét nem eldöntô, hanem csak a szavazatok arányára kiható tényezôként megemlíthetô az ellenzéki pártok hataloméhes marakodása és egymással szembeni, összefogásra képtelen rivalizálása, amely a választásokat követôen többüknek belsố szervezeti széteséséhez, a lemondásokkal összefüggố megüresedett tisztségekért történô tülekedéshez vezetett. Egyúttal a szavazók a választásokat megelôzó kampányukból kiérezték, hogy semmi konstruktívat mondani nem tudnak, és csak koncepciótlanul támadják a kormányt, miként ezt teszi és tette Brüsszel és a Soros-birodalom is. Ez a választásokat követôen is folytatódott és folytatódik jelenleg is, melyre oda kell figyelni.

A VÁlASZTÁSOKAT KÖVETŐ ELLENZÉKI AKCIÓK, VALAMINT A VELÜK SZEMBENI VÉDEKEZÉS SZÜKSÉGESSÉGE

Az ellenzéki pártokat hidegzuhanyként érte a választási eredmény. Egymást okolták az összefogás elutasítása miatt, és már a választást követô másnapon választási csalást, újbóli szavazatszámlálást, sôt a választások megismétlését követelte az ellenzék vala- 
mennyi pártja, immár együttesen. Az ellenzéki pártok „sugallatára” a „másként gondolkozó demokratikus érzelmú sokaság” ösztönzésére, meghirdették a permanens demonstrációkat, amelyeket mindaddig folytatni akartak, míg a kormány nem enged, és meg nem hátrál. Ezért ellenintézkedésként a kormány az új parlament elsố tavaszi ülésszakának elején benyújtotta, a parlament pedig abszolút többséggel megszavazta, Alaptörvény-kiegészítéssel megalapozva, az eredeti elképzeléshez mérten szigorított törvénytervezetet, amellyel a tüntetések szervezését végző, Soros György-féle civil szervezetek múködése megszüntethetô, a szervezetek kitilthatók legyenek az országból, bel- és külföldi aktivistáik pedig órizetbe vehetôk és büntetôjogilag felelôsségre vonhatók legyenek. A Büntetô törvénykönyv új tényállással történt kiegészítése értelmében az illegális bevándorlás szervezésének bármilyen módon történő tényleges elősegítése, propagálása vagy abban való közremúködés búncselekménynek minôsül. Egyúttal helyes lenne, ha a fốbüntetés a külföldi elkövetôk kiutasításán kívül, azt megelőzốen, a belföldi állampolgárokkal egyezően, mellékbüntetésként ingyenes közmunkára kötelezéssel is kiegészülne, ha cselekményükkel kárt is okoztak, ami ily módon helyrehozható lehetne. Helyes jogalkotási lépés volt az is, hogy más országokhoz hasonlóan Magyarországon is a pénzügyi és adójogi elôírások kibôvítésével, a civil szervezetek és az alapítványok kötelessé váltak külföldrôl származó adományaikat bejelenteni és azok után adót fizetni, amely adót és eme előírások megszegéséért járó szabálysértési bírságokat az állam a migráció feltartóztatásával összefüggó kiadások fedezésére köteles fordítani. Az is helyes, hogy ez kibôvül a 25\%-os ún. „bevándorlási különadóval", amelyet elsôsorban az olyan szervezetnek kell megfizetni, amely a bevándorláshoz pénzügyi vagy pénzügyileg elszámolható támogatást nyújt. Eme új törvényt pedig teljes szigorral és következetességgel lesz szükséges alkalmazni a generál és a speciál prevenció érdekében.

Ezzel a bevándorlási különadóval várhatóan eredményesen lehet majd fellépni a Helsinki Bizottság, a Velencei Bizottság, valamint a Soros Alapítványok és a többi NGO-szervezetek által szervezett olyan rendezvényekkel és tanfolyamokkal szemben is, amelyeket már eddig is folytattak és folytatnak ma is, bevonva az igazságszolgáltatásban dolgozó bírákat, ügyészeket, ügyvédeket, végrehajtókat és a közigazgatásban dolgozó köztisztviselôket is. Sôt, újabban igyekeznek kiterjeszteni ezt az ún. „érzékenyítô” jogszolgáltatói felfogást és tevékenységet a vallási felekezetekre is. Nyilván ennek érdekében tüntették ki a liberális alapítású Károly-lánccal Ferenc pápát, és hívták meg a Bilderberg-csoport ez év tavaszi ülésére a Vatikán külügyi bíborosát. A cél a kontinentális jogot megtisztítani eredeti „helyes jogtani”, jogdogmatikai-jogelméleti jellegétôl és írásban lefektetett, jogbiztonságot adó egzakt fogalmaitól, valamint alkotmányban rögzített alapelveitől, az így keletkezô ûrt pedig kitölteni a politikai célszerúség alapján a mindenkori érdekigényekhez alkalmazkodó jogmagyarázattal. Pokol Béla A jurisztokratikus állam címú könyvében mutatja ki, hogy miként történt az amerikai jogrendszer és jogelmélet, valamint jogalkotás és jogalkalmazás átvételével a jog kiforgatása, amelynek filozófiai alapját a frankfurti iskola és annak prominens képviselóje, Jürgen Habermas adja (Pokol, 2015:36-37). Tóle származik az „újjog” alapját képezó új morálelmélet, mely szerint kétféle morál létezik. Az egyik a történelem folyamán a 
társadalomban kialakult általános, ún. közönséges morál, amelynél sokkal fejlettebb és a jog alapját képezi az ún. diszkurzus morál, amelyet a hozzáértô „entellektüelek” szúk köre alakít ki, és erre kell hogy épüljön a korunk igényeinek megfeleló jog. Ez pedig az amerikai jogon nyugszik, amit az USA Legfelsőbb Bírósága alakít ki abból adódóan, hogy az USA alkotmánya meglehetôsen hézagos. Ezen az alapon, mutat rá Pokol Béla, az alkotmánybíróságok alkotmányellenesnek minôsítve megváltoztathatnak olyan alaptörvényeket és törvényeket, amelyeket többségi határozattal az egyes országok parlamenti képviseló-testülete fogadott el. Ezenkívül pedig a bíróságok, részben átvéve a transzatlanti angolszász ítélkezési gyakorlatot, a tételes jogi előírásokat is a rendelkezô szöveg tartalmától eltérôen, a mindenkori politikai célkitûzéseknek megfelelően magyarázhatják, elvonatkoztatva a jogszabály-interpretálás hagyományos logikai, nyelvtani és történeti értelmezési elóírásoktól. ${ }^{5}$

Ma már egyértelmúen látható, hogy az USA-nak a kormányzásból kikerült demokrata párti politikusai a „nyílt társadalom” ideológiájával, az ENSZ, az Unió egyes szervei és vezetô tisztségviselôi felhasználásával, ha nem is lakosságcserét, de lakosságkeveredést kíván végrehajtani Európában annak érdekében, hogy civilizáltság és múveltség, a munkaerô-képzettségi színvonal tekintetében Európa országainak társadalmai leépüljenek, ezzel elôsegítve, hogy az európai államokat az USA gazdaságpolitikai érdekeinek alávessék. Európa az Afrikából és Elô-Ázsiából Európába tömegesen érkezôk alacsonyabb múveltsége, kultúrája és szaktudása folytán gazdasági és kulturális színvonala miatt egyaránt lesüllyedne. Azt pedig, hogy itt nemcsak lakosságkeveredés, hanem fajkeveredés elérése a cél, mutatja, hogy a nem politikai menekültként, hanem gazdasági migránsként érkezôk többsége egyedül érkezô fiatal férfi. Mindez Coudenhove-Kalergi 1924-ben publikált páneurópai koncepcióján nyugszik, amellyel összhangban állt a kortárs nyelvlogikai szintaxis filozófiai irányzatát hirdetô osztrák Wittgensteinnek a Bertrand Russell matematikaelméletére kidolgozott „világnyelvtana”, amelyre a galíciai származású, lengyel Zamenhof felépítette a közös Európa nyelvét, az eszperantót (Prugberger, 2016b; 2018b:14-17). A migránsáradat megindulása óta szerzett gyakorlati tapasztalatok megcáfolták azt az elképzelést, hogy a nyugat-európai országok igen alacsony születési rátája miatt rohamosan elóálló munkaerőhiány ily módon pótolhatóvá válik. Pokol Béla már jóval korábban megírta, hogy a muszlim iskolát végzett migránsok megszerzett tudása nem éri el az európai munkaerôktôl az egyes szakmákban elvárt szakképzettségi szintet, és ezért nem jó munkaerôk. ${ }^{6}$ Ugyanakkor dolgozni sem akarnak, hanem csak a jóléti nyugat-európai államok által nyújtott segélyekből, valamint búnözésból kívánják eltartatni magukat. Megmutatkozott az is, hogy az ellenôrizetlenül érkezô migránsok egy része radikális iszlamista és az ISIS által beszervezett terrorista. Ennek következtében 2015 és 2017 között több nyugat-európai államban, így Franciaországban, Belgiumban, Hollandiában, Németországban, az Egyesült Királyságban és Svédországban jó néhány tömeges halálesettel járó terrorcselekményt hajtottak végre szélsôséges iszlamista terroristák, többet pedig sikerült időben felderíteni. Nơk és gyermekek szexuális zaklatása a migránsok részérôl mindennapos, és úgyszintén az utcai vagyonfosztogatások is. Kimutatható, hogy ezekben az országokban a közbiztonság katasztrofálisan romlott, és az emberek sötétedés után 
nem mernek az utcára menni. Ezenkívül fennáll a veszélye annak, hogy a menekültek olyan trópusi betegségeket hozhatnak be, amelyek ellen az európai lakosság nem immunis, ennélfogva trópusi betegségek járványszerú terjedése tizedelheti meg az európai ôslakosságot.

Minthogy ez az ideológia teljesen tudománytalan, embertelen és társadalomidegen, Európa teljes tönkretételével fenyeget. Emiatt is indokolt a minden oldalú társadalmi érdekegyeztetést megvalósítani, amit azonban a munka világában éppen a szocialista szakszervezetek lehetetlenítettek el (Prugberger, 1998). Ugyanakkor az érdekegyeztetés általánossá tételét jelentô javaslatot 2002-ben a miskolci Bíbor Kiadónál megjelent Érdek és érdekegyeztetés a jogban címú könyvemben megírtam (Prugberger, 2002). Akkor ez a nézetem a hatalomra került balliberális kormány részéról süket fülekre talált. Emiatt a 2018. évi parlamenti választásokat megelőzó kampány során az Orbán-kormány helytállóan verte vissza az ellenzéki politikus abbeli kritikáját, hogy az Orbán-kormány a munka világában felszámolta a háromoldalú megállapodáskötésre lehetôséget adó országos érdekegyeztetést. Én magam is kifogásoltam, javaslatként felvetve, hogy a Nemzeti Gazdasági és Társadalmi Tanács keretein belül álljon vissza az országos munkaügyi érdekegyeztetés (Prugberger, 2013:7). Ez mintegy három éve meg is valósult. A gyakorlat most már ez. Igaz, még csak informálisan, de múködik, és hátravan még a jogszabályi formális visszaállítása.

Álláspontom szerint nagyon is jelentôsek ezek a kérdések, amelyekre reagálni szükséges. Egyértelmú, hogy a kétharmados választási eredmény elsôsorban a migránskérdés nemzeti érdekeknek, nem pedig Brüsszel álláspontjának megfeleló kormányzati kezelésének köszönhetô. Ugyanakkor az Európai Unió az általuk feltételezett korrupció és jogállamisági deficit vádjával igyekezett a parlamenti választásokat követô, kormánybuktatásra irányuló hétvégi tüntetésekhez muníciót adni. Ezért volt lényeges, hogy az újonnan megválasztott parlament mindjárt a tavaszi ülésszakában megszavazta a fent már részletesebben tárgyalt ún. Stop Soros törvényt. Brüsszel egyre erôteljesebben koncentrálva kívánja a Sargentini-jelentés felhasználásával elérni azt, hogy az Európai Parlament néppárti frakciója zárja ki a sorából a Fidesz-KDNP-t, és a lisszaboni szerzôdés 7. cikkelyének alkalmazásával vonják meg Magyarország szavazati jogát.

Közelebbről vizsgálva a Sargentini-jelentés tartalmát, az tele van olyan ferdítésekkel és valótlan állításokkal, amelyek kimerítik a rágalmazás tényét. A jelentés készítôje antiszemitizmussal vádolja a kormányt és a kormányfơt. A közismert tények és a kormány, valamint a kormányfố hazai és külföldi intézkedései és Izrael Állam, a hazai és a külföldi zsidó vallási szervezetek, valamint az amerikai nagykövet visszajelzései mindennek a cáfolatát és az ellenkezőjét, a kormány és a miniszterelnök filoszemita politikáját jelzik vissza. Ezzel összefüggésben a rasszizmus is alaptalan vád. Az Európai Unió és a migránsok befogadását támogató kormányok vezetôi a migránsok által elkövetett atrocitások és gyilkosságok miatti jogos demonstrációk résztvevőit minden alapot nélkülözve antiszemitizmussal és neonácizmussal rágalmazta.

Más azonban a helyzet a Sargentini-jelentésben szerepló rágalmazás esetében, amelyet a jelentés készítője konkrétan egy kormánnyal, vagyis a kormány elnökével és tagjaival szemben követett el. Tette mindezt olyan módon, valamennyi tagállam jog- 
rendjét érintve, amely miatt valamennyi tagállam büntetóeljárást indíthatna a magyar miniszterelnök kormányának valamennyi tagjával szemben. Ezért megfontolás tárgyát képezhetné hogy a magyar kormány elnöke és tagjai Sargentini asszonnyal szemben az Európai Emberjogi Bíróság előtt eljárást indítsanak. Ez elindíthatna egy lavinát más tagállamokban is, ami megfontolásra késztetné a migráns-politikusokat, hogy a valótlan állításoktól tartózkodjanak.

Ami pedig a Sargentini-jelentés európai parlamenti megszavazását illeti, helyesen teszi a kormány, hogy annak érvénytelenné nyilvánítása miatt az Európai Törvényszékhez fordul, mivel a jelentés anyagi és eljárásjogi szempontból is defektes. Anyagi jogi hibát jelentô ferdítések és valótlanságok egy részérôl a rágalmazás kapcsán előbb már szó esett. A demokráciadeficit és a jogállamiság felszámolása vádjának ellentmond a háromszor kétharmados kormányalakítási megbízáson túl az is, hogy az ellenzék által a külföldi balliberális politikai erôk segítségével szervezett tüntetések nem érték el a tömegdemonstráció szintjét, és kifulladtak. Ugyanakkor a magyar kormány migrációt gátló politikájával a magyar választóknak csak egy elenyészô kisebbsége nem ért egyet.

Ami a jelentés alaki hibáját illeti, a szavazás egyértelmúen érvénytelen a jogetikai normák szerint is. A tételes jogi európai jogrendszerekben éppen úgy, mint az angolszász esetjogi rendszereknél, évszázados hagyományként alakult ki, hogy minden kollektívában a szavazásos döntéseknél, a szavazatszámlálás során a tartózkodó szavazatokat is figyelembe kell venni, mert azok is állásfoglalást jelentenek. Az ily módon kialakult gyakorlat miatt a római és a lisszaboni szerződésben ez a kérdést kissé elnagyoltan, viszont az évszázadok szokásával összhangban rendezték. Ezért a történeti, logikai és nyelvtani jogértelmezés eredménye sem lehet más. Egy jogerôvel rendelkezô normatív szabályzatban lefektetett intézményt meg lehet változtatni, de csak megfelelô eljárási rend betartásával, és csak a jövốre nézve és tartós jelleggel. Egy cél elérésére történô alkalmi változtatás - mint amilyen a Sargentini-jelentés feletti szavazás volt rendellenes joggyakorlásnak minôsül. Nyílt jogellenesség és célzatos alkalmi változtatás nyilvánult meg abban is, hogy a szavazás rendjének módosításáról szóló tervezetet a Sargentini-jelentéstől függetlenül kellett volna a plénum elé vinni, önálló napirendi pontként, és erről az ülés résztvevőit legalább nyolc nappal az ülésre történô meghívó kiküldése során, abba foglalva, indokolással együtt írásban értesíteni.

Azért is érdemes egy kenyértörésre alkalmas fellépést tenni az Európai Unió brüszszeli irányításával szemben, mivel Brüsszel, a Helsinki Bizottság és Soros „Nyílt Társadalom” alapítványhálózata azzal is vádolja a magyar kormányt, hogy fel akarja számolni a bírói függetlenséget, és olyan bírósági felügyeleti intézményt kíván létrehozni, amellyel áttételesen befolyásolni tudná az ítélkezést. Ez az uniós álláspont is több sebból vérzik. Az írásom elején, Pokol Béla kutatásai alapján szóltam arról, hogy mind az Európai Emberjogi Bíróság, mind az Európai Unió Bírósága és a Tribunal, mind pedig a liberális kormányzás alatt álló tagállamok alkotmánybírósága és rendes bíróságai az USA Legfelsôbb Bíróságának, valamint alsóbb bíróságainak tételes jogi szabályokhoz nem vagy csak lazán kötött esetjogi jogalkalmazásából fakadó ítélkezési gyakorlata magában hordja a szubjektív voluntarizmus veszélyét. Ezt a veszélyt az angolszász, fóleg a kontinentális brit jogrendszerben csökkenti az, hogy ahol nincs normatív tartalmú 
act, vagyis pozitív jog, ott az ítélet meghozatalánál jogszabályhely meghivatkozása helyett egy vagy több hasonló ügyben meghozott ítélettel kell alátámasztani. Mint már korábban szó esett róla, az Európai Unió eme angolszász jogrendszerhez hasonlóvá kívánja átalakítani a pozitív jogon alapuló kontinentális ítélkezést. Ezért teszi lehetôvé mind az alkotmány, mind a rendes bírósági gyakorlat számára az adott tényálláshoz tapadó írott jogszabályhely szövegének a korábbi korlátokat felrúgó szabadelvú és liberális politikának megfelelő magyarázatát (Pokol, 2015:36-37).

Ilyen módon, a szerzódéskötési szabadság elvére hivatkozva utasította el a hazai bírói gyakorlat a 2010-ben hatalomra jutott Orbán-kormány keresetét az elôzó kormány által kifizetett óriási összegú végkifizetések érvénytelenségének a kimondásáról, amelyet jó erkölcsbe ütközó szerzôdés semmisségére hivatkozással indított meg. A Bajnai-kormány ugyanis olyan munkáltatói látszatfelmondások és közszolgálati felmentések után fizetett ki nagy összegú végkielégítéseket kádereinek, akik munkaviszonyuk, közalkalmazotti, illetve köztisztviselói jogviszonyuk névleges megszúnése után ugyanazt a tevékenységet vállalkozási vagy megbízási jogviszony alapján folytatták tovább. Hasonlóképpen a balliberális politikai irányvonalnak megfeleló ítélet született a Kúria részérôl, amikor érvénytelennek minôsítette azoknak a magyar állampolgársággal rendelkezó kárpátaljai magyaroknak a szavazatát, akik úgy jöttek át a határon túlról magyar területre szavazni, hogy a kormány fiktív módon egy közös lakhelyre jelentette be óket. Tette ezt azért, mert ha kitudódott volna magyar állampolgárságuk, az ukrán hatóságok retorziójaként elvesztik ukrán állampolgárságukat. Itt lehetôség lett volna a „ius equity” alkalmazására, a Kúria viszont a formális jogot, a „ius strictet” alkalmazta, és érdekes módon a balliberális irányzatoknak kedvezve megszorító módon interpretálta a jogszabályi szöveget.

Az Orbán-kormány az Alaptörvénybe betette, a köztisztviselóknek a 70. éves életkor betöltésével járó nyugdíjaztatásával szemben a bírák nyugdíjazására a 62. életkor betöltésével kerül sor. Az Európai Bizottságnak ezzel kapcsolatos kritikáját részben elfogadva, a köztisztviselók nyugdíjkorhatárát is 65 évre leszállította a kormány a közalkalmazottakra és a köztisztviselókre egységesen érvényesülóen. Ebból kitûnik, hogy a bírói kar egy jelentôs részének a polgári kormányhoz való viszonya enyhén szólva még mindig ambivalens. Meg kívánom azonban jegyezni, hogy az Orbán-kormány már a hivatalba lépésekor megtehette volna, hogy a bíróságok minden lépcsőfokán leváltja az elnöki, kollégium, és tanácsvezetői tisztségrôl a tisztséget betöltô bírákat, és helyükre kormánybarát bírákat nevez ki, akik az ügyek elosztása során a politikai szempontból kényes ügyeket polgári beállítottságú bírákra és ilyen tanácsokra szignálják ki. Ez gyakori volt a Horthy-korszakban, még inkább azonban a szocialista korszak egész időszakában. Az Orbán-kormány azonban ezzel a lehetôséggel a 2010-es választással történt hatalomra kerülésétôl fogva egyszer sem élt.

A generációváltással azonban remélhetôleg javulni fog az igazságszolgáltatás színvonala és az ítélethozatali tárgyilagosság. A tárgyilagosság mellett azonban fontos a szakmai színvonal-emelkedés is. Ehhez viszont elmélettel karöltött, gyakorlatorientált oktatásra van szükség, amely csak kis csoportos foglalkoztatással, vagyis a gyakorlatokat kis létszámú, 10-15 fős tankörök részére gyakorlat szempontjából is felkészült oktatók 
Prugberger Tamás: A Fidesz-KDNP-pártszövetség választási gyốzelmének tényezôi...

tartsák. Ehhez azonban nem elég az egyszer elsajátított reproduktív tudás, hanem folyamatos kutatással produktívnak is kell lennie a jogot oktatóknak. Ez megkívánja, hogy fennálljon a kontaktusa a joggyakorlattal is, és ha ügyvéd, csak olyan ügyeket vállaljon, amelyek oktatási-kutatási területével áll összefüggésben. E téren szükséges a legnagyobb változtatás. A közalkalmazotti jogviszonyban álló oktatónak ugyanis elsôsorban oktatónak kell lennie, és csak másodsorban legyen ügyvéd. Ma ugyanis informálisan épp a fordítottja érvényesül. Ehhez viszont az is szükséges, hogy a kormány ne törje a fejét a jogi karok csökkentésén, és az egyes oktatók állása ne attól függjön, hogy az egyes időszakokban mennyi hallgató, illetôleg óraszám esik rá. A jogi képzésre, de általában az egész felsôoktatási képzésre is áll, hogy az oktatókat, hogy hivatásukat teljes értékben gyakorolni tudják, társadalmi hasznosságuk arányában kellene megfizetni, hogy megélhetési és családfenntartási gondjuk ne legyen.

Az eddig tárgyaltakat figyelembe véve, a kormánynak addig, amíg a transzatlanti és az európai külpolitika nem tisztul meg a jelenlegi szélsóbal-liberális globalista irányvonaltól, résen kell lennie, és ügyes diplomáciával kell politizálnia azon elvek fel nem adása mellett, amelyeknek köszönhette a mostani kétharmados választási győzelmét. Ehhez viszont a migránskérdésben az eddigi kemény irányvonal fenntartása, a vállalkozási szféra fejlődésének a segítése, a munka világában a munkavállalói szociális jogok bôvítése, a foglalkoztatás további növelése, a közalkalmazotti és a köztisztviselói státuszbiztonság erôsítése, a közszolgálat hagyományainak megfelelő, méltányos privilégiumok megadása, a nyugdíjak értékállandóságának megóvása és az életszínvonal mérsékelt, de folyamatos emelése, valamint az oktatás- és az egészségügy felzárkóztatása szükséges. A közvélemény ezenkívül még elvárja a korrupciómentes kormányzást. Erre most fokozottan ügyelni kell, ugyanakkor azonban a közjó érdekében a kormány segítségével a tehetséges, unortodox beállítottságú hazai vállalkozókat továbbra is indokolt segíteni a növekedésben. Ezt viszont meg kell magyarázni a közvéleménynek, hogy ennek össztársadalmi haszna van.

\section{REFLEXIÓK A KORMÁNYZATI STRUKTÚRA ÁTALAKÍTÁSÁHOZ}

Idôközben megalakult az új Orbán-kormány. Az elôzetes beharangozáshoz képest nagyobb változtatásokra számítottam nemcsak a személycserék, hanem strukturális vonatkozásokban is. Egy korábbi tanulmányomban kritizáltam a kormányon belüli túlcentralizációt (Prugberger, 2016a:43-46). Ugyanakkor el kell ismernem, ez az Emberi Erôforrások Minisztériuma kivételével bevált az e tárcákat vezetô miniszterek rendkívüli munkabírásának, szervezô- és vezetési készségének köszönhetôen. Ezt figyelembe véve a pénzügy és a nemzetgazdaság Varga Mihály szaktudása és munkabírása következtében egy minisztériumon belül maradhatott volna. Az új kormányzati struktúra értelmében a tárca pénzügyminisztériummá „,vékonyodott”. Az Orbán-kormány pénzügyi politikája és monetáris igazgatása mindvégig helytállónak tûnt és túnik. ${ }^{7}$ Lehet azonban, hogy a Pénzügyminisztériumon belül egy igen erôs ipari és belkereskedelmi államtitkárság alakul ki, magában foglalva a kereskedelem és piacfelügyelet országos irányítását. Ha erre nem kerülne sor, az arra utalna, hogy a kormányfó a belgazdaság 
tekintetében az állami beavatkozás nélküli liberális ipart és belkereskedelmet preferálná. Magam részérôl az indirekt állami gazdaságirányítás és a visszaélésekkel szembeni állami kereskedelem- és piacfelügyeleti ellenőrzés Nyugat-Európában kialakult modelljét jónak tartom. Ezért helyénvalónak tartanám egy ipar- és belkereskedelem-felügyeleti minisztérium létét. Egy ilyen megoldás azért is célirányos volna, mert egy közelgô gazdasági válság előszeleit érezni. Nagyon helyesen, ennek figyelembevételével készült a jövô évi költségvetés, amelyben a pénzügyminiszter a korábbi költségvetési tartalék kétszeresére növelt, 2019. évre tervezett mértékét a felével még megemelte. Ez a megnövelt összegú tartalékalap elegendô lehet az amerikai és a kínai vámháború, valamint a 2008-as gazdasági válság óta ismét felfújódott lufik kipukkanása káros hatásainak a kezelésére (Jakubász, 2018:13). Ugyanakkor Csaba László aggasztónak tartja, hogy az extrém laza monetáris és fiskális politika következtében még mindig nincs kamatemelés, holott bizonyos visszafogásra a lakosságot fel kellene már készíteni. Problémának látja még azt is, hogy a tôke nem a gazdaságba, hanem lakásvásárlásokba fektetődik be. Ez szerinte arra utal, hogy bizalomhiány áll fenn, ami jogos annyiban, hogy a válság hatására több vállalkozás tönkremegy majd, a túlélők azonban korszerúsíteni és innoválni fognak. Ugyanakkor Csaba László szerint a termelőipari vállalkozások egy részének a tönkremenetelével párhuzamosan a szolgáltatói szférában cégnövekedés várható, ami felszívhatja majd az állásukat elvesztôket is (Hajdú, 2018:6-7).

Ehhez viszont a munkaerő képzését, átképzését korszerúsíteni és a társadalmi igényekhez igazítani szükséges. Csaba László szerint a mai képzés nem felel meg ennek (Hajdú, 2018:6-7), ezért indokolt lenne a német képzési-átképzési rendszert átvenni, amire a külföldi megoldások figyelembevételével, Jakab Nórával együtt tettem javaslatot (Prugberger-Jakab, 2013:88-104). Ennek megvalósulása indokolttá tenné, hogy visszaálljon egy munka- és foglalkoztatásügyi minisztérium, vagy az innovációs minisztérium keretein belül egy ilyen jellegú, erôs államtitkárság alakulna meg. Ennélfogva pedig, hogy minden vállalkozási és munkavégzési, egyszóval legális jövedelemszerzési tevékenységben a gazdasági hatékonyság szempontjából is magasan, de legalábbis megfelelôen kvalifikált, valamint kulturált és ezáltal konstruktívan gondolkozó egyének vegyenek részt, a jelenleginél is nagyobb hangsúlyt kellene fektetni a közoktatásra. Bár a 2019-es költségvetés az egészségüggyel együtt az oktatásügy költségvetését is lényegesen megemelte, Csaba László azt még mindig kevésnek tartja (Jakubász, 2018:13), és hasonlóan vélekedik a szakszervezetekkel együtt Facsinay Kinga is (Facsinay, 2018). Mindketten elismerik, hogy mindkét területen van előrelépés, azonban tárgyilagosan történik utalás arra is, hogy az oktatás- és az egészségügy fejlesztéséhez szükséges anyagi forrásokból sokat elvisz az utódnemzés növelését célzó családpolitika és a migrációval szembeni védelem. Ez utóbbit azonban igen helyesen csökkenteni fogja a migráció elősegítésének a megadóztatása, amit a migrációval szembeni intézkedésekre lehet csak fordítani (Facsinay, 2018). Az ezáltal felszabaduló pénzt indokolt lenne az oktatásra és az egészségügyre fordítani, illetve az Emberi Erőforrások Minisztériumát egy oktatási és kulturális, illetve közegészségügyi minisztériummá szétválasztani, és az eddigi „mega-” minisztériumból kiválna a munka-, foglalkoztatás- és szociálisügyi minisztérium. E minisztérium keretében volna helyes kiépíteni osztrák 
mintára a vállalkozóképző hálózatot, amely az álláskeresôket ingyen képezné ki vagy át vállalkozóknak, majd a tanfolyam befejezését követôen minden részvevônek ingyen követné nyomon a beindított vállalkozását, és adna tanácsot részükre több éven keresztül, ami különösen a gazdasági és pénzügyi tervezés és beszámoló elkészítésére vonatkozna (Hajdú, 2018:6-7). Ez azért is lényeges, mert a legtöbb kormányközeli közgazdász, köztük Csath Magdolna és Lentner Csaba is, a vállalkozói szféra erôteljesebb fejlesztése mellett szál síkra. ${ }^{8}$

Végezetül szükséges utalni arra, hogy komoly társadalmi ellenállásba ütközik az a terv, hogy az Innovációs és Technológiai Minisztériumhoz kerüljenek át a Tudományos Akadémia kutatóintézetei, amit az Akadémia mint önkormányzati köztestület kutatóhálózatának ingatlanaival együtt történó államosításaként él meg. Lényegében ilyen felállásban múködik az osztrák és a francia tudományos akadémia, amely két akadémiához szintén nem tartoznak kutatóintézetek. Egy közel hetvenéves átrendezôdést azonban egyik napról a másikra radikálisan átalakítani - mint ez bizonyítást is nyert - lehetetlen, és széles körú társadalmi ellenállást vált(ott) ki. Ugyanakkor azzal, ha az itt említett minisztériumhoz kerülne át az akadémiai kutatóhálózat, félő, hogy ennek az alapkutatás látná a kárát. Tartok tôle ugyanis, hogy eme új minisztérium a jelenlegi profilja alapján háttérbe szorítaná nemcsak az alapkutatásokat, hanem az összes társadalomtudományi kutatást is. Itt jó lenne, ha e minisztérium profilja kiegészülne egy olyan tudományirányítási profillal, amely jellemezte az Antall-kormány Pungor Ernô akadémikus által vezetett ehhez hasonló minisztériumát. Ennek megfelelően indokolt lenne a jelenlegi Innovációs és Technológiai Minisztériumot Innovációs, Technológiai és Tudománykoordináló Minisztériummá átszervezni. Ezzel összhangban pedig valamennyi kutatóintézetet továbbra is akadémiai keretek között hagyva olyan önkormányzattal múködtetni, amelyben részt vesz e minisztériumon keresztül az állam. Ezért minden intézeti tanácsban, de ugyanígy az Akadémia legfelsô tanácsában is képviselettel rendelkezhetne az állam is, hasonlóan, mint ahogy ez a német társadalombiztosítás és általában a nyugat-európai társadalombiztosítás intézményrendszerében van. Egy ilyen kompromisszummal a tudományos közeg részben indokolt ellenállása is kiküszöbölhetô volna, ugyanakkor azonban a kormány szintén részben indokolt igénye is megvalósulhatna.

Hasonlóképpen volna helyes a társadalmi ellenállást elkerülni azzal, ha a kormány letenne a kafetéria Brüsszel által indokolatlanul igényelt kivezetésével. Arról van szó ugyanis, hogy rendelettel kötelezôvé tette a foglalkoztatói nyugdíj kiegészítô nyugdíjkénti bevezetését, amely utáni járulékot, illetve tagsági díjat a főszabályként a munkáltató és a munkavállaló közösen fizetnék. Ugyanakkor a foglalkoztatói kiegészítô nyugdíjat zárt körú részvénytársaságként múködő nyugdíjintézetek üzemeltetik, és így a biztosítottaknak és a járulékot befizetố munkáltatóknak nincs belelátásuk, hogy a zrt. mire fordítja a befizetéseiket. Ezért, annak ellenére, hogy Magyarország a rendeletet a magyar jogrendszerbe átültette, a foglalkoztatási kiegészítő nyugdíj nem múködik, és mindenki a kafetériához ragaszkodik. Mind a munkáltatók, mind a munkavállalók érzik, hogy itt a multik részérôl egy újabb pénzszivattyú múködik (Barta-Prugberger, 2015:553). 
Mindent összevetve, álláspontom az, hogy mind az olyan több profilt összevont minisztériumoknál, mind az olyan hagyományos profilúaknál, és minden olyan fóhatóságnál és országos intézménynél, ahol lakossági vagy egyéb társadalmi érdek jelenik meg, az intézmény mellett az eme érdekeket artikuláló társadalmi szervezetek „kooptálásával" alakuljon intézményi tanács, amelyben az intézmény vezetôje, pl. a miniszter látja el az elnöki funkciót. E tanácsnak kellene elôzetesen megtárgyalni minden esetben a kormány részére benyújtandó törvényjavaslatokat.

\section{JEGYZETEK}

1 Az 1998. áprilisi koalíciós megállapodás értelmében, amelyet a Fidesz és a Kisgazdapárt kötött meg egymással, a Kisgazdapárt elnöke, Torgyán József lett a mezôgazdasági miniszter, Peppó Pál pedig a környezetvédelmi miniszter. A mezôgazdasági tárca politikai államtitkára Szabadi Béla lett. E két tárca múködése e három személy miatt meglehetôsen ellenmondásos, autoriter és magukat a kormányfôtốl függetlenító volt.

22001 második és 2002 elsố felében több kormánynyilatkozat hangzott el a gázenergia visszavásárlásának szándékáról a médiában (MTV1, Kossuth Rádió, HírTv).

3 KSH-adat 2018. III. n.év és Eurostat-adat 2018. I. és II. negyedév.

4 Szakszervezeti bírálat Schröder-Blair-nyilatkozatról, FES Tallózó, 2000/1. sz.

5 Pokol, 2015, 1. fejezet (f.) 1-2. pont(p.), 2. f., 3. p., 4. f., 5. f. 2-4. p., 6-7. f.

6 Pokol, 2011, II. és III. fejezet.

7 Vö. Lentner, 2016, 17. fejezet.

8 Lásd Csath Magdolna írásait a Magyar Idók véleményrovatában, továbbá Lentner, 2016, 15. fejezet

\section{FELHASZNÁLT IRODALOM}

Barta Judit (2011): Visszatérés az egypilléres kötelezô nyugdíjrendszerhez. Gazdaság és Jog, 19. évf., 3. sz., 9-15. Barta Judit - Prugberger Tamás (2015): A foglalkoztatói kiegészítô nyugdíj megszervezésének és finanszírozásának útjai az Európai Gazdasági Térség államaiban és Magyarországon. In: Lentner Csaba (szerk.): Adózási pénzügytan és államháztartási gazdálkodás. Közpénzügyek és államháztartástan II. NKE Szogáltató Kft., Budapest.

Facsinay Kinga (2018): Nagy vesztes az oktatás és a szociális ellátás. Magyar Hang, június 22-28., 7.

Friedrich Ebert Alapítvány (2003): Harmadik utak - Új közép. Szociáldemokrata reformpolitika a globalizáció korszakában. Friedrich Ebert Alapítvány, Bonn.

Gazdag László (2017a): Magyar gazdaságpolitika: dilettantizmus a köbön. Kapu, 29. évf., 9. sz., 31-36.

Gazdag László (2017b): Baloldal: Elkúrtuk, de hol? Kapu, 29. évf., 10. sz., 30-32.

Hajdú Péter (2018): Csaba László: Közelít a válság, s mi nem készültünk fel rá. Magyar Hang, június 22., https://magyarhang.org/gazdasag/2018/06/22/csaba-laszlo-kozelit-a-valsag-s-mi-nem-keszultunk-fel-ra/.

Jakubász Tamás (2018): A kormány felkészül a kihívásokra. Varga Mihály: Nem ismétlődhet meg idehaza a 2008-as gazdasági összeomlás. Magyar Idôk, június 26., https://magyaridok.hu/gazdasag/a-kormanyfelkeszul-a-kihivasokra-3232801/.

Lentner Csaba (1996): Ki fizeti (meg) a privatizációt? Gazdaság és Társadalom, 7. évf., 3-4. sz., 36-50.

Lentner Csaba (2016): Rendszerváltás és pénzügypolitika. Akadémiai Kiadó, Budapest.

Magyar Idốk (2018): Az unió tagjai egyenrangúak. Orbán Viktor kormányfó beszéde a Helmuth Kohl emlékére rendezett konferencián. Magyar Idôk, június 19., https://magyaridok.hu/belfold/az-unio-tagjaiegyenranguak-3211258/.

MH (2018): A világszervezet dekriminalizálná a határsértéseket, erôsítené a nagy népvándorlási folyamatokat elôsegítố és kiváltó tényezôket. Magyar Hîrlap, június 5. 


\section{Prugberger Tamás: A Fidesz-KDNP-pártszövetség választási győzelmének tényezői...}

Pokol Béla (2011): Európa végnapjai. A demográfiai összeroppanás következményei. Kairosz Kiadó, Budapest.

Pokol Béla (2015): A jurisztokratikus állam. Dialóg Campus Kiadó, Budapest.

Prugberger Tamás (1993): Mennyiben eredményes a hazai privatizáció. Gazdaság és Társadalom, 4. évf., 5. sz., 64-68.

Prugberger Tamás (1997): A nyugat-európai és a közép-kelet-európai országok privatizációinak jogi rendezésérôl. In: Ünnepi tanulmányok Gáspárdy László professzor 60. születésnapjára. Novotni Alapítvány, Miskolc.

Prugberger Tamás (1998): Munkaügyi és szociális érdekegyeztetés, de hogyan? Valóság, 41. évf., 11. sz.

Prugberger Tamás (2002): Érdek és érdekegyeztetés a jogban. Bíbor Kiadó, Miskolc.

Prugberger Tamás (2005): A jog múködésének korlátai Magyarországon a gazdaság szociál-liberálkapitalista belsố és külsố környezetében. Gazdaság és Társadalom, 16. évf., 1. sz., 29-57.

Prugberger Tamás (2009): Politikai felelôsség közjogi, büntetô- és polgári jogi felelősséggel kiegészítve. Polgári Szemle. 5. évf., 6. sz.

Prugberger Tamás (2011): A magyar kötelezô nyugdíjrendszer reformja a magánnyugdíjpénztárak ellenében és a reform továbbvitelének lehetôsége nyugat-európai mintára. Gazdaság és Jog, 19. évf., 3. sz., 15-19.

Prugberger Tamás (2013): A munkaügyi kapcsolatok új szabályai az érdekkiegyenlítés jegyében. Gazdaság és Jog, 21. évf., 3. sz., 3-10.

Prugberger Tamás (2016a): Közigazgatási és közszolgálati reform centralizálással és leépítéssel - kritikai vizsgálat. Új Magyar Közigazgatás, 9. évf., 2. sz., 43-49.

Prugberger Tamás (2016b): Milyen kalandor nagyhatalmi és titkos politikai erôk irányítják a jelenlegi migránsáradatot? Mi húzódik meg a színfalak mögött, és mi lehet az ellenszer? Valóság, 59. évf., 6. sz., 16-25.

Prugberger Tamás (2018a): Jogpolitológiai és politikafilozófiai elmélkedés közvetlenül a 2018. április 8. parlamenti választások után. Kapu, 30. évf., 4. sz., 13-18.

Prugberger Tamás (2018b): Korunk általános eszmei, morális és gazdasági, valamint szociál- és jogpolitikai társadalmi válságának világnézeti gyökerei és az e válságból való kilábalás lehetôségének a felvetése. Карu, 30. évf., 2. sz., 10-18.

Prugberger Tamás - Jakab Nóra (2013): A foglalkoztatás elôsegítés és igazgatás joga. Bíbor Kiadó, Miskolc.

Szájer József (2018): Sargentini a kapuk elôtt. A kiegyensúlyozott LIBE-bizottság ülésén a liberáis tolerancia nevében belém fojtották a szót. Magyar Idôk, június 23., https://magyaridok.hu/velemeny/sargentinia-kapuk-elott-3216034/,

Szôcs László (2018a): Erôsebb határokat akar Merkel és Macron. Magyar Idôk, június. 20., https:/ / magyaridok.hu/kulfold/erosebb-hatarokat-akar-merkel-es-macron-3213118/.

Szốcs László (2018b): Európa vezetői belátták, le kell zárni a határokat. Merkel elismerte: Orbánnak igaza van. Magyar Idôk, június 12., https://magyaridok.hu/kulfold/europa-vezetoi-belattak-le-kell-zarni-a-hatarokat-3185503/.

Varga Judit (2018): A jogállam megcsúfolása. Sargentini jelentés: kijátszották a nyilvánosságot és magát a demokráciát is. Magyar Idók, június 26. sz., https://magyaridok.hu/velemeny/a-jogallam-megcsufolasa-3231262/. 